\title{
(RE)PENSANDO A CONSTRUÇÃO DA NAÇÃO PORTUGUESA NO MEDIEVO
}

\author{
Rethinking the CONStRuction Of the Portuguese nation In the Middle Ages
}

Denise da Silva Menezes do Nascimento* menassil@yahoo.com.br

RESUMO: Na discussão sobre os elementos de unidade portugueses devemos destacar as relações existentes entre Estado, nação e identidade enfatizando a ideia de nação como um fenômeno de longa duração, a fim de trazer à tona a importância da Idade Média na constituição da identidade nacional portuguesa. Nessa perspectiva iremos analisar a importância dos mitos de origem para consolidar sentimentos de pertença e coesão do povo lusitano em torno de um agente de poder que se mostrava capaz de garantir a manutenção do bem comum e a justiça equitativa.

PALAVRAS-CHAVE: Identidade nacional portuguesa, Idade Média, mito.

ABSTRACT: When discussing the Portuguese unit elements, it is necessary to highlight the relations involving State, nation and identity. In doing so, the idea of nation as a long term phenomena is pointed out, in order to evidence the importance of Middle Ages to the constitution of the Portuguese national identity. In this perspective, it is analyzed here the importance of the origin myths to consolidate the Lusitani sense of belonging and cohesion towards an agent of power who appeared to be capable of ensuring the maintenance of common welfare and equitable justice.

KEYWORDS: Portuguese national identity, Middle Ages, myth.

Uma historiografia mais tradicional vê vínculos indissociáveis entre Estado, nação e nacionalismo, mas, como tem apontado as pesquisas no campo da história político-conceitual, esta não é uma concepção deslocada de seu tempo histórico, o que implica em mudanças de significação de tais conceitos a partir dos paradigmas de análise dos pesquisadores. Por um lado, o termo nação é prioritariamente associado às identidades de pessoas que viviam num mesmo território submetidas a autoridade de um monarca, mas na medida em que a conotação social é ampliada, nação estará cada vez mais associada a um grupo social específico de um determinado território - cidadãos - que goza de determinados direitos políticos e sociais. Neste caso, ou seja, no uso contemporâneo corrente, os vínculos entre Estado, nação e cidadania serão cada vez mais estreitos. Todavia, outras possibilidades de entendimento, dependentes do período analisado, são verificadas. Tal nos permite discutirmos as relações existentes entre Estado, nação e identidade no período medieval atentando para a importância das especificidades e elementos de coesão e unidade daquele momento com especial atenção aos mitos que fundam uma unidade política (Afonso

\footnotetext{
* Doutora em História Social pela Universidade de São Paulo (USP) e Mestre em História Comparada pela Universidade Federal do Rio de Janeiro (UFRJ). Professora adjunta na Universidade Federal de Juiz de Fora, atuando no Programa de Pós-Graduação em História da UFJF e no Mestrado Profissional do Programa de Pós Graduação em História Ibérica da Universidade Federal de Alfenas (UNIFAL).
} 
Henriques), uma dinastia (D. João I) e um novo tempo histórico (D. João II). Nesse sentido, é preciso ter em mente que

os atributos da comunidade étnica são, nesta abordagem, em grande medida os mesmos que servem para identificar a nação: um nome próprio coletivo; um mito de ancestralidade comum; memórias históricas partilhadas; um ou mais elementos diferenciadores próprios de uma cultura comum; uma associação com uma terra natal específica; um sentido de solidariedade para setores significativos da população. Porém, para que uma etnia se transforme em nação - processo que nada tem de inevitável - será necessário que satisfaça outros critérios acima enunciados: que partilhe um território e uma economia comuns, uma mesma cultura de massas, esteja submetida a uma mesma ordem jurídica, etc. Por outras palavras, essa transformação depende da história dessa mesma etnia e nomeadamente do impacto do estado. Um outro autor, que recentemente pôs em causa a hipótese de uma origem moderna das nações - e nomeadamente a de que estas seriam uma criação dos nacionalismos -, Josep Llobera (1994), localizou na Idade Média o ponto de partida de emergência das nações (SOBRAL, 1999, p. 78).

No tocante ao Medievo, a construção da nação é um processo que está intimamente ligado ao momento histórico segundo o qual é estabelecido e repensado o jogo das diferenças e semelhanças, do Eu e do Outro. E no que diz respeito a Portugal, os monarcas acima referidos foram fundamentais na consolidação do Eu em comparação com o Outro castelhano, desempenhando papel de inegável relevância na afirmação de mitos identitários que contribuíram para a construção da nação portuguesa.

Entre os muitos contributos para a definição de uma tipologia dos nacionalismos, um dos precursores, Hugh Seton-Watson, recorreu a um dos critérios mais simples, fundado sobre os diferentes contextos históricos em que os diferentes processos de construção do estado-nação se desenvolveram. Foi nesta perspectiva que Seton-Watson começou por distinguir as velhas das novas nações. Mais do que um critério de maior ou menor ancestralidade, a distinção baseava-se no fato de haver um conjunto de nações europeias que tinham desenvolvido os seus processos de construção nacional, muito antes do que poderemos designar por era das nações e dos nacionalismos (JUSTINO, 2011, p. 49).

$\mathrm{Na}$ categoria de velhas nações europeias encontram-se os ingleses, escoceses, franceses, holandeses, castelhanos e portugueses; e para defender tal enquadramento, o autor analisa os elementos formadores da identidade nacional, destacando o poder do Estado, a religião, a língua, o descontentamento social e as pressões econômicas. Estes países caracterizam-se pela construção de um Estado centralizado ao longo da época Moderna frente aos modelos tradicionais das cidades-estado do Mediterrâneo ou dos estados feudais do leste da Europa (JUSTINO, 2011, p. 50). As Velhas Nações, que integram o chamado "arco 
atlântico", assentaram a estruturação de seu espaço e economia num importante poder naval e na mercantilização do Estado, o que por sua vez não pode ser dissociado da afirmação de uma administração mais centralizada.

Tomando como referência a categorização de Seton-Watson, podemos observar que a formação desses Estados Modernos não era sustentada por movimentos sociais nacionalistas, mas sim pela afirmação do poder real frente aos demais poderes constituintes da sociedade e pela territorialização desse poder que se estendia para além das fronteiras terrestres europeias, ou seja, alcançava os novos domínios além-mar. Não ter como base movimentos de caráter nacionalista significa que estas sociedades não estavam organizadas em torno de uma identidade? Debruçando-se sobre essa questão, Vitorino Magalhães Godinho propõe a separação entre os processos de estruturação das nações em relação ao processo de desenvolvimento dos nacionalismos. E, para tanto, analisa o caso português identificando a "Era dos Nacionalismos" ao período contemporâneo e a estruturação das nações, das velhas nações, ao final da Idade Média e início dos Tempos Modernos (GODINHO, 2004).

Esta separação admitiria, assim, a existência de nações antes dos nacionalismos contemporâneos e estruturadas a partir de um reduzido mas decisivo conjunto de pilares fundacionais (...): um território entendido como 'configuração espacial traçada por fronteiras' e espaço de exercício de soberania; uma comunidade assente em laços de solidariedade e cimentada por uma vontade de viver em comum, concretizando o que Ortega y Casset definia por 'comunidade de propósitos'; uma sociedade organizada a partir de um conjunto diferenciado de 'instituições que formam um complexo de poder (capacidade coactiva) - o Estado'; um laço afetivo 'que liga os indivíduos à coletividade', expresso através de um sentimento de Pátria, 'porque nele se consubstanciam a memória coletiva, a consciência e o amor pelo patrimônio comum e as aspirações em relação ao porvir' (JUSTINO, 2011, p. 51).

Esta separação defendida por Godinho não deve, todavia, descartar fatores identitários de ordem cultural, tais como a língua, a religião e os mitos fundacionais, posto que estes aspectos reforçam as especificidades e permeiam o processo de afirmação e expansão da identidade lusitana na e para além das fronteiras ibéricas.

No texto Identidade, Estado e o paradigma da centralização, José Esteves Pereira, buscando entender a inserção e as especificidades de Portugal no contexto ibérico faz uma análise do paradigma da centralização aliado aos conceitos de espontaneidade, resistência e atlanticidade. Para o autor, a condição definidora da identidade portuguesa está atrelada a 
expansão das fronteiras do mundo lusitano, tanto no que diz respeito aos conflitos e convivência com o Islã quanto às ações geopolíticas da expansão atlântica. “De fato, se como nação e como Estado nos constituímos por uma fronteira terrestre, na Península também temos e sempre tivemos uma fronteira ativa que é o Atlântico. Foi essa a via que nos deu acesso aos espaços africano, americano e asiático" (PEREIRA, 2011, p. 68).

A expansão das fronteiras no universo peninsular e no Além Mar também deram a tônica da ideia de soberania e poder central, na medida em que o poder régio era legitimado por sua função de defensor da Res Publica Christina. Na condição de guardião da fé e do bem comum, o rei se colocava a frente nos campos de batalha e acima dos demais grupos constituintes da sociedade. Consumava-se assim não apenas a definição das fronteiras, mas também a salvaguarda do povo e da Igreja, bem como as relações de subordinação e unidade em torno de um ideal e de um poder unificadores. Por seu turno, ter nas mãos do monarca o comando militar contra os infiéis não dá conta de explicar a subordinação e/ou aliança das elites em torno de um elemento aglutinador. E, nesse sentido, devemos destacar a atuação da monarquia no estabelecimento de um "organismo político capaz de assegurar uma administração impessoal e uma autoridade a que mesmo os poderes senhoriais tinham de se sujeitar, independentemente de compromissos recíprocos de vassalidade" (MATTOSO, 2000, p. 14). Nesse sentido, no século XIII já observamos a preocupação com a promulgação de um conjunto de leis, com a organização das finanças da coroa e com a formação de juristas e administradores capazes de auxiliar o monarca na condução dos negócios do reino e expansão da fronteira lusitana.

O domínio de territórios ibéricos e regiões africanas por Portugal estava desde longa data assentado na descendência reivindicada pelo povo lusitano em relação aos visigodos que expandiram seu poder aos moradores romanos da Península e do norte da África. Considerando que a expansão visigótica se impôs em solo lusitano e tinha atingido a região de Marrocos e que cabia a todo monarca cristão impedir a expansão dos infiéis e recuperar as terras que agora estavam sob o domínio destes, o interesse no Além Mar estava justificado e sua ação conquistadora se via legitimada (SERRÃO, 1998, p. 20). Combater o Outro religioso no continente europeu e conhecer e conquistar ilhas e demais terras em África, sob posse de infiéis e gentios, significava a possibilidade de alargar a Cristandade e disponibilizar bens e honras em proveito daqueles que auxiliavam o monarca em tal tarefa. Tais feitos também 
serviam ao propósito de destacar o reino lusitano entre os mais importantes da Europa; a Coroa portuguesa via-se diante da oportunidade de se engrandecer frente à Cúria Romana, interessada em aumentar o número de fiéis, aos vizinhos castelhanos que se sentiam herdeiros dos visigodos e por isso também vislumbravam a possibilidade de dominar os mares ocidentais, bem como frente aos demais estados mercantis europeus interessados em ampliar seus negócios nas praças africanas.

A necessidade de aumentar a arrecadação de recursos implicou num maior controle dos bens senhoriais, eclesiásticos e concelhios, o que por sua vez levou a elaboração de tombos dos bens dos grandes senhores, bem como a uma reforma dos forais no intuito de normatizar as contribuições a que os diferentes grupos sociais estavam obrigados. Todos no reino tinham obrigação de ajudar no custeio das expedições: a nobreza com suas armas na Reconquista e na tomada de cidades africanas, os concelhos e grupos mercantis com investimentos e impostos; nem os dízimos eclesiásticos escapavam das terças que incidiam, com a autorização papal, sobre as rendas da Igreja. A expansão das fronteiras e da fé contribuía, assim, para a construção do ideal de unidade e identidade, consumando "a identificação entre Nação e Estado. Só a partir desta realidade se pode enquadrar a complementaridade subjacente à natureza do poder, quando visto no plano das relações do temporal e do espiritual" (PEREIRA, 2011, p. 71). Portugal irá afirmar suas especificidades associando a identidade nacional à necessidade de recorrer ao Estado como a entidade capaz de impor uma ordem, preservar a memória e congregar todos no propósito de expansão da fé e do território (JUSTINO, 2011, p. 61).

Sabemos que o processo de formação de Estados Nacionais não é uno, diferentes estratégias e práticas foram encontradas na afirmação da nação e na constituição das identidades. Todavia, podemos afirmar que

Entre coincidências e divergências, este conjunto de países [velhas nações] preenchiam já, no dealbar da era das nações, um conjunto de requisitos que os movimentos nacionais dos restantes países europeus estavam longe de assegurar: territórios e fronteiras de há muito estabilizados, línguas nacionais consolidadas e generalizadas, sociedades organizadas em torno de Estados modernos e comunidades assentes ora em propósitos coletivos, ora em laços de solidariedade e afetividade, que conferiam alguma coesão indispensável à ideia de nação. Daí que a lógica de afirmação das nações na Europa tenha de ser entendida de forma diferenciada (JUSTINO, 2011, p. 52). 
No século XXI, ao (re)pensarmos a formação dos Estados Nacionais não podemos, portanto, nos restringir ao estudo dos nacionalismos europeus do século XIX, já que pensar o próprio povo brasileiro nos remete a Portugal no momento da expansão marítimo-comercial, ou seja, nos obriga a discutir a formação do Império Marítimo Português e a olhar a identidade nacional lusitana sendo forjada ainda no período medieval.

Comumente afirmamos que o período medieval é marcado pela fragmentação política, pela hegemonia religiosa e cultural da Igreja Católica e pela sociedade tripartida (os que oram, os que guerreiam e os que trabalham). Não podemos, todavia, esquecer que a tão citada centralização política Moderna (em oposição a difundida debilidade dos reis medievais) se fará num lento processo que pressupõe a coesão social em torno de um agente de poder que se mostra capaz que garantir a manutenção do bem comum e a justiça equitativa. Nesse sentido, pensar as relações estabelecidas entre o poder régio e a burguesia na centralidade política do rei pressupõe a não exclusão dos demais atores sociais. Em outras palavras, a formação dos Estados Nacionais - em Portugal, mas não apenas lá - está intimamente ligada à construção de mitos, heróis e símbolos nacionais que acionem mecanismos de identificação e pertença dos diferentes grupos constituintes da sociedade. Identidade e união que são constantemente revividos na memória coletiva.

No processo de construção nacional são particularmente relevantes os mitos de origem, de escolha, de fundação da pátria e os que reproduzem as "épocas douradas". O uso do mito para forjar ou consolidar as consciências nacionais, levando à criação de sentimentos de identidade nacional, foi uma fórmula recorrente de construção nacional. Os tempos, os protagonistas, as ações que se transformam em mitos, não se desenvolvem desregradamente, isto é, sem que exista uma ação que se responsabilize pelo conteúdo da narrativa. O historiador Eric Hobsbawm, numa perspectiva claramente modernista/instrumentalista, contextualizou através da "invenção da tradição" a ação das elites na produção de mitos e símbolos que, pelo seu papel agregador junto das massas, teriam funcionado nos últimos duzentos anos como elementos catalizadores na construção das identidades nacionais. No contexto do paradigma modernista do nacionalismo, de uma maneira geral, enfatiza-se o papel do Estado e das elites neste processo, assumindoos claramente como "mythmakers" (AMANTE, 2011, p. 223).

Nos oitocentos e início do século XX, temos uma larga produção centrada na questão da identidade nacional. Os estudos antropológicos voltados para a cultura popular afirmavamse como uma 'antropologia de construção da nação', "o seu objetivo era fundamentar a nação como uma 'comunidade étnica de descendência', baseada em antecedentes étnicos providos dos argumentos de antiguidade e originalidade, uma 'etnogenia' peculiar e remota de que a 
cultura popular era o testemunho" (PEREIRA, 2001, 141). Pensar a nação e a identidade não é, contudo, uma exclusividade das centúrias de oitocentos e novecentos. Em pleno século XXI, esta ainda é uma questão que permeia os debates de historiadores, antropólogos, literatos, dentre outros estudiosos. Nas reflexões sobre nação e nacionalismo, podemos destacar as obras que se opõem as teses que defendem o nacionalismo como um fenômeno político moderno. "No contexto da ampla teorização do nacionalismo, o mito impõe-se como elemento analítico nas teses etnosimbólicas defendidas por Anthony Smith que inclui os 'mitos e as memórias históricas' entre os elementos definidores das identidades nacionais" (AMANTE, 2011, p. 221).

Dentre os mitos que serviram de amálgama para a sociedade lusitana, podemos destacar o de Afonso Henriques, guerreiro que alicerça a fundação de um Estado cristão e autônomo. Elemento de unificação e coesão da sociedade, Afonso Henriques forja, através da guerra contra o infiel, alianças com a Igreja desejosa de aumentar seu domínio temporal e espiritual e com a nobreza ciente das possibilidades de ver seu poder econômico e administrativo ampliado. Dos espólios de guerra obtidos em terra inimiga (bens e cativos), uma parte era revertida ao rei (o quinto), ficando o restante com os membros da expedição, fossem eles clérigos ou leigos. Todavia, vencer o infiel não era suficiente, era preciso repovoar o território e para tanto, o rei praticou uma política de doação de terras e direitos administrativos e prerrogativas de defesa. Assim, a chefia militar trouxe também a associação dos conselhos e da nobreza que "cedendo uma parte de suas prerrogativas ao rei nas áreas militar, da justiça e do fisco (...), podiam negociar com o rei o reconhecimento de importantes privilégios e prometiam a colaboração de seus exércitos na luta antiislâmica" (MATTOSO, 2000, p. 13). A guerra contra os muçulmanos no Condado Portucalense uniu o sentido militar com o político, tornando prementes as estratégias de apropriação, defesa e povoamento do território, o que por sua vez, foi elemento fundamental no estabelecimento de alianças entre realeza, Igreja e nobreza. O mito então se constituía e se difundia a partir das relações de amizade, dependência e reciprocidade entre a monarquia e os dois estados formadores da sociedade portuguesa - os que oram e os que guerreiam. Afonso Henriques cada vez mais se anunciava como monarca, aquele capaz de "unir todos os segmentos sociais, justamente por sobrepor-se a eles, formando uma unidade reconhecível por todos, que viria a constituir a nação portuguesa". O vitorioso guerreiro das batalhas de Ourique (1139) e São Mamede 
(1128) se apresentava "como aquele que reunia as qualidades necessárias para a promoção dessa unidade" (COSER, 2007, p. 708).

Nesse processo, associação entre mito e identidade nacional, ganham destaque a mitificação de espaços e objetos tal como observamos com o castelo de São Mamede em Guimarães. Na primeira metade do século XIX, Alexandre Herculano teve papel relevante no processo de identificação dos castelos com a própria identidade portuguesa, sociedade viril e valente capaz de imolar a vida de valorosos guerreiros na consolidação e expansão do reino português. Assim, na política independentista de Afonso Henriques a batalha de São Mamede ganha destaque na luta contra os castelhanos. O Castelo de São Mamede será lembrado como importante espaço de defesa contra as incursões de Afonso VII de Leão e Castela e como testemunha imponente e inextinguível da luta e vitória de Afonso Henriques sobre D. Teresa e os barões galegos desejosos de se apoderarem da governança da região. A partir da Batalha de São Mamede, o castelo será alçado ao símbolo de testemunha ocular da vitória lusitana em favor da definição de suas fronteiras e do caminhar a passos largos em direção a formação do reino português, elementos tidos como fulcrais para a existência de sentimento de pertença, unidade e identidade. Esta imagem personificada não será esquecida e ao lado do mito fundador de Afonso Henriques, tal como apontado por Joaquim Manuel Rodrigues dos Santos, "o regime ditatorial do Estado Novo contribuiu enormemente para a sublimação do Castelo de São Mamede com 'Berço da Nação' e explorou ideologicamente a figura do próprio castelo medieval como sendo um herói nacional" (SANTOS, 2017, p. 166).

Uma característica frequentemente associada à narrativa mítica é o seu carácter "fantástico" e não necessariamente verossímil, isto é, algo que o torna inacessível para os homens comuns. Os heróis míticos têm um quê de excepcional, funcionam como ideais, o mesmo acontecendo com os tempos narrados que também se apresentam como profundamente distantes do tempo presente, irrepetíveis, e, portanto, excepcionais. Os heróis míticos totalizam e recriam constantemente a história humana e abolem o tempo (AMANTE, 2011, p. 221).

Eventos históricos decisivos na história das sociedades, tal como a mudança de dinastia em Portugal e as vitórias sobre os castelhanos, são os mais susceptíveis de mitificação tanto do evento histórico quanto de um personagem. Assim, D. João I, mestre de Avis ganha destaque na consolidação de uma identidade lusitana pautada na aliança entre todos os grupos sociais, incluindo a burguesia e a 'arraia miúda'. Rede de amizade e solidariedade 
crucial na construção de um império marítimo português e no estabelecimento de uma supremacia lusitana no domínio de territórios, posse de riquezas e difusão da fé cristã.

Se Afonso Henriques era o personagem histórico que forjou a autonomia portuguesa frente aos demais reinos ibéricos, D. João I, filho bastardo do rei D. Pedro I e de Teresa Lourenço, por ocasião das lutas sucessórias que culminaram no fim da dinastia de Borgonha, viria a ser o 'Messias de Lisboa', aquele que possibilitou a manutenção da independência de Portugal. A continuidade da dinastia de Borgonha foi questionada na medida em que a herdeira do trono era casada com o rei de Castela, implicando na submissão ao reino vizinho, o que desagradava tanto ao terceiro estado quanto aos interesses de parte da nobreza. Além disso, o rei de Castela fora excomungado por apoiar o anti-papa Clemente VII contra o chefe da Cristandade estabelecido em Roma, o que, segundo os interesses lusitanos, invalidava o seu poder perante os súditos portugueses, que se mantiveram fiéis ao papa Urbano VI. Devemos também destacar que as guerras com Castela "ao trazerem tropas estrangeiras a Portugal, evidenciavam as diferenças estre portugueses e os outros, isto é, aqueles que falavam outra língua, tinham outros costumes e se comportavam como inimigos" (MATTOSO, 2000, p. 16).

Diante da possibilidade de Portugal ser governado por um estrangeiro cismático, o clero, parte da nobreza, a burguesia e a arraia miúda consideraram o trono vacante e se uniram em torno de D. João I, Mestre de Avis. Tendo adquirido popularidade por sua participação nas lutas contra Castela e sendo contrário a uma pretensa união ibérica, ele se apresentou como a possibilidade de manter a independência de Portugal e a conservação da verdadeira fé cristã, sendo por isso conhecido pelo povo como o "Messias de Lisboa", ou seja, aquele que estava predestinado a salvar o reino do jugo de um tirano estrangeiro. Esta imagem foi reforçada com a vitória do Mestre de Avis sobre o rei castelhano que invadira Portugal, pelo que foi aclamado "Defensor do Reino". "Assim como acontece na tradição messiânica dos hebreus, estamos diante da concepção de uma 'elite', que faz a interpretação da história contemporânea por intermédio de um mito. Uma série de episódios contemporâneos recebe uma articulação e uma interpretação que se conforma com o modelo atemporal do mito heróico" (ELIADE, 1992, p. 40). A vitória rápida do monarca na batalha de Aljubarrota serviu para confirmar que Deus o tinha escolhido para manter a paz no reino. D. João I era, portanto, rei eleito pelos três estados do reino nas cortes de 1385 e confirmado por Deus (NASCIMENTO, 2009, p. 23); o messias do povo lusitano frente aos cismáticos castelhanos.

Um outro João, o segundo da dinastia de Avis também desempenhou papel relevante na consolidação dos sentimentos de pertença e de unidade do povo lusitano. No final do século XV o poder judicial estava nas mãos dos reis, dos senhores laicos e eclesiásticos e dos concelhos municipais, ou seja, estava disperso em muitas mãos; dispersão contra a qual D. João II vai lutar. O objetivo do rei era "tutelar os demais poderes que desejavam ver como coadjutores, seus delegados, jamais poderes 
concorrenciais" (COELHO, 1990, p. 110). D. João II incentivou a produção de um discurso legitimador, que promovia o rei a uma posição de superioridade, na medida em que o monarca deveria ser visto como o elemento capaz de unir os diversos grupos constituintes da sociedade. "Tão logo a personalidade histórica de [D. João] recebeu acolhida junto à memória popular, ela foi abolida, e sua biografia obteve uma completa reconstrução, que se conformava com as normas do mito" (ELIADE, 1992, p. 41). E, nesse sentido, a imagem de Príncipe Perfeito deveria comportar as virtudes corporais - "beleza, agilidade, força, liberdade, saúde, voluptuosidade e longevidade" (SOUSA, 1996, v. 2, p. 8) - consolidando a ideia de um rei forte e belo. Mas, para além destas e das demais qualidades físicas, temos em D. João II um rol de atributos, as sete virtudes, que fazem dele um Príncipe Santo e Perfeito: as teologais, ou seja, fé, esperança e caridade, e as cardiais, a saber, fortaleza, temperança, prudência e justiça. E nos conflitos com Castela, D. João buscou coadunar as virtudes com o objetivo de evidenciar que todos os seus atributos seriam usados a fim garantir um bom governo, que certamente incluía a justiça dos súditos e a supremacia do reino.

Castela também estava, portanto, no centro das atenções de D. João II, que tal qual o primeiro de sua dinastia entrou em conflito com o reino vizinho em virtude de problemas sucessórios estabelecidos com a morte do monarca castelhano, Henrique IV, que determinou por testamento que ao trono Ihe sucederia sua única filha, que por sua vez deveria se casar com seu tio e rei de Portugal, D. Afonso V. Recaía sobre a herdeira da coroa a suspeita de ilegitimidade na sucessão, posto que era acusada de ser filha de um romance ilícito da rainha. A esta acusação somou-se o receio de que o casamento entre a herdeira do trono e $\mathrm{D}$. Afonso $\mathrm{V}$ culminasse numa união ibérica com a prevalência do reino lusitano, fazendo com que parte da nobreza castelhana se tornasse simpática ao reinado de Isabel de Castela, que obteve o apoio militar necessário para enfrentar o rei português na luta pela sucessão dinástica.

A fim de garantir o cumprimento do testamento do monarca falecido, a defesa da honra de sua esposa e sobrinha e de assegurar a entronização que implicaria na supremacia de Portugal na Península Ibérica, D. Afonso V iniciou um conflito armado com Castela. A nobreza lusitana ofereceu apoio ao intento, posto que encontrava na guerra a oportunidade por excelência de aumentar seus senhorios, honras e privilégios na medida em que ao cumprir a obrigação feudal de ajudar militarmente seu senhor, os nobres eram recompensados pela lealdade e ajuda prestada ao monarca. Preparada a guerra, em 1475, o rei D. Afonso V partiu para invadir Castela, deixando como regente o príncipe D. João.

Após conseguir submeter várias praças e angariar a ajuda de nobres castelhanos contrários aos Reis Católicos, a vitória portuguesa parecia certa. Mas eis que as razias sofridas e denunciadas pela população e a política de perdão régio concedida pela rainha Isabel a todos os súditos que oferecessem 
ajuda militar a Castela, somado ao retorno de vários senhores para Portugal, começaram a minar o apoio ao monarca lusitano e a reverter a situação em favor de Castela. Diante das dificuldades enfrentadas por $D$. Afonso $V$, o príncipe $D$. João acorre com seu exército a cidade de Toro a fim de ajudar militarmente seu pai.

Com a chegada do reforço iniciou-se uma batalha divida em duas frentes, uma sob o comando do rei $D$. Afonso $V$ e outra sob a liderança do príncipe $D$. João. $O$ exército de $D$. Afonso foi desbaratado, o que levou o rei castelhano a se retirar do local de batalha na condição de vencedor. Por outro lado, os homens sob o comando do príncipe D. João impuseram franca derrota ao exército dos Reis Católicos, que ficou carente de homens em virtude de mortes e deserções. Convém ressaltarmos que a vitória do príncipe permitiu que Portugal não negociasse o fim da guerra em desvantagem. Ambos os reinos reivindicavam a vitória na Batalha do Toro e o príncipe português soube tirar proveito de tal situação, pois na condição de vitorioso podia negociar um acordo de paz com vantagens para Portugal.

A guerra com Castela terminou com a assinatura do Tratado de Alcáçovas, em 1479, do qual o príncipe D. João participou ativamente nas negociações. No acordo constava que D. Afonso V e sua esposa D. Joana renunciavam ao trono castelhano, ficando determinado que esta se recolheria a um convento. Uma outra cláusula do tratado de paz estabelecia as Terçarias de Moura, segundo a qual a filha dos reis castelhanos e o filho de D. João ficariam nesta região sob a guarda da duquesa de Viseu, D. Beatriz, posto que esta mantinha relações de parentesco e amizade com ambos os reis, sendo tia da rainha Isabel e sogra de D. João II. Esta parte do acordo selava a paz e amizade entre os dois reinos através do matrimônio, pois foi determinado que quando alcançassem a idade apropriada os jovens se casariam, cabendo a Portugal receber a título de dote e indenização de guerra a quantia de cento e seis mil, seiscentas e setenta e seis dobras de bom ouro. Por fim, o Tratado de Alcáçovas selava a paz nos mares entre os reinos ibéricos, reconhecendo o domínio lusitano sobre a costa africana e as ilhas atlânticas. Em contrapartida, Portugal aceitava a posse das Canárias por Castela. Ambos os reinos se comprometiam a se respeitarem mutuamente, punindo com severidade os súditos que ousassem comercializar no Atlântico sul sem o consentimento do monarca português ou fazer incursões nas Canárias sem a prévia autorização de Castela. Assim, pelo acordo de paz firmado com Castela, o príncipe D. João contribuía para pôr termo a um importante conflito iniciado por seu pai, D. Afonso V, além de garantir o domínio do continente africano.

Parte do que conhecemos sobre D. João II nos chegou através de seu cronista, Garcia de Resende, que se encarregou de deixar para a posteridade os feitos do monarca a fim de que a verdade dos fatos não caísse no esquecimento e que as atitudes do Príncipe Perfeito 
em prol de seu povo fossem perpetuadas. No século XV, a língua portuguesa ganha cada vez mais espaço na escrita administrativa, no cerimonial e na literatura; é também nesse momento "que apareceram as primeiras crônicas e histórias do território e da dinastia régia, nas quais se estabelece a grelha dos principais mitos do passado português" (CARDIM, 1998, p. 139). Este foi, portanto, um momento chave na organização da memória coletiva portuguesa e Garcia de Resende, moço de escrivaninha do rei, foi testemunha ocular dos acontecimentos dos últimos decênios do século XV e seu

testemunho é, num sentido, uma extensão da memória, tomada na sua fase narrativa. Mas só há testemunho quando a narrativa de um acontecimento é publicitada: o indivíduo afirma a alguém que foi testemunha de alguma coisa que teve lugar; a testemunha diz: "creiam ou não, em mim, eu estava lá". O outro recebe o seu testemunho, escreve-o e conserva-o. O testemunho é reforçado pela promessa de testemunhar de novo, se necessário; o que implica a fiabilidade da testemunha e dá ao testemunho a gravidade de um sermão. (RICOUER, s/d, p. 3)

Por sua política de fortalecimento do poder régio, cuja administração era fundamentada no bem comum, bem como na sedimentação da imagem do monarca como vitorioso chefe militar na luta contra o Outro político e cismático, D. João foi tido por muitos como a aurora anunciadora dos tempos modernos. Época em que ganhavam novos contornos a arte de bem governar, "a arte e a ação de dominar, de ser dono ou guia de súditos, de dirigir populações e territórios - eis a compreensão de política" (SOUSA, 1996, v. 2, p. 3). Arte e atributos usados em tempos de guerra e de paz para garantir a superioridade dos lusitanos frente aos castelhanos e aos muçulmanos. Ações que permitiram a D. João consolidar a imagem de soberano defensor do povo, território e interesses portugueses. Imagem que ajuda forjar o mito do "Príncipe Perfeito". Mito, que "enquanto narrativas, reproduzem atores e fatos ocorridos num tempo distante, que foram perdurando na memória coletiva e que, na perspectiva do etnosimbolismo são um dos elementos que permite estabelecer a ligação entre o passado e o presente das nações, fortalecendo sentimentos de pertença e capacidade de imaginação coletiva" (AMANTE, 2011, p. 222).

\section{Considerações Finais}

A nação é concebida como uma ampla comunidade, unida por laços que não se resumem à submissão a um único soberano, nem à pertença a uma única religião ou a um mesmo estrato social. Não é o monarca que a determina, sendo a sua existência independente dos acasos da história dinástica ou militar. (...) O que faz a nação, segundo Renan, "é um legado rico de 
recordações", "tal como o indivíduo é o resultado de um longo passado de esforços, sacrifícios e devoções". (...) A nação nasce de um postulado e de uma invenção. Mas só se mantém viva com a adesão colectiva a essa fiç̧ão. As tentativas falhadas são inúmeras. Os sucessos são fruto de um proselitismo tenaz que ensina aos indivíduos o que são, obriga-os a conformarem-se e incita-os a difundir, por sua vez, esse saber colectivo. 0 sentimento nacional só é espontâneo quando já está totalmente interiorizado; tem de ser ensinado previamente. (THIESSE, Anne-Marie, 2011, p. 70-72)

Pensar a história medieval portuguesa, tanto em termos de acontecimentos quanto no que diz respeito a escrita sobre determinados fatos, implica na necessidade de nos debruçarmos sobre a importância dos textos dedicados aos temas da formação da nação e do nacionalismo. Não porque acreditamos que a concepção contemporânea de nação existisse no Medievo, mas porque os fatos narrados (e os preteridos), bem como os personagens selecionados (e esquecidos) estão intimamente ligados a uma concepção de história disseminada a partir dos anos de 1800, que buscava exaltar os elementos que permitiram a formação da nação e os feitos gloriosos do Estado lusitano. E nós, historiadores, nos vimos como uma das principais ferramentas nas lembranças interiorizadas e perpetuadas.

Na escrita da História o principal cuidado devia consistir em levar a narração como um fio ininterrupto e em perfeita ligação e (...) como primeiro dever do historiador, antes de se lançar a escrever, escolher matéria formosa, agradável, nobre e tal que simultaneamente deleite o espírito do leitor e o instrua com ótimos exemplos morais, isso quem o não vê zelosamente conseguido por ti? De fato, escolheste para descrever e transmitir à mais remota posteridade os feitos de João II, Sereníssimo Rei de Portugal e Príncipe Perfeito, e não sei que tema mais grato, mais nobre e mais digno da eterna memória dos homens se podia escolher (SILVA, 1989, p. 17).

A citação acima é de finais do século XVII e foi escrita por Dom Carlos José de Ligne, príncipe do Sacro Império Romano, em carta felicitando o Marquês de Alegrete por este ter empreendido esforços para escrever sobre a vida e feitos de Dom João II. De acordo com a citação acima, a escrita da História implica em escolha orientada conforme nossos propósitos. Diante do desejo de escrever sobre um rei que pudesse servir de modelo de bom governante, o Marquês de Alegrete destacou a figura de Dom João II por considerar que este monarca, reunia os atributos morais e políticos necessários à condução do povo e do país a um lugar cimeiro no cenário europeu.

Manuel Telles da Silva, marquês de Alegrete, foi camareiro e conselheiro do então príncipe dom Pedro, futuro D. Pedro II. No reinado deste, o marquês teve importante participação nas questões diplomáticas portuguesas, cabendo a ele a celebração do Tratado de Mútua Aliança (1701) entre as 
coroas lusitana e espanhola. Também ficou sob sua incumbência as negociações que culminaram no Tratado de Methuen (1703), importante acordo comercial entre Portugal e Espanha. Sendo nomeado regedor da Justiça em 1669, coube a ele trazer respeitabilidade à administração reorganizando a justiça, que segundo o monarca dom Pedro se achava em estado de precariedade e ineficiência. Como conselheiro do rei com participação ativa nos negócios do reino, e tendo em vista exemplificar para as gerações futuras o que seria um bom governo, pautado no princípio de equidade na aplicação das leis, Manuel Telles da Silva escreveu em latim a Vida e feitos de D. João II. Mas "sendo costume dos escritores não publicarem qualquer escrito sem um defensor" (SILVA, 1989, p. 13), o marquês solicitou o apoio de D. Pedro II, que prontamente o concedeu, posto que concordava tratar-se D. João Il de "um modelo perfeito de rei" (SILVA, 1989, p. 10), um exemplo a ser seguido por todo monarca que desejasse impor sua autoridade sobre os súditos e que tivesse como norte de seu governo a ideia de fortalecer a reputação de Portugal no cenário internacional.

Portugal se afirma na Idade Média como uma sociedade orientada pelo ideal de Reconquista e submissão do Outro e consolida sua força nos Tempos Modernos a partir de sua vocação atlântica de conversão de infiéis e pagãos. Nesta perspectiva ganha destaque a ideia de nação como um fenômeno de longa duração, trazendo à tona a importância dos mitos dos períodos pré-modernos na constituição da identidade nacional. Afonso Henriques, D. João I, D. João II. Exemplos a serem seguidos. As características do mito foram (re)pensadas e (re)apropriadas pela coletividade, possibilitando o que Maria de Fátima Amante considera uma transposição temporal, da Idade Média para outros períodos históricos, reafirmando um conjunto de valores e o sentimento de pertença; enfim, incidindo na construção da identidade e nação lusitanas.

\section{REFERÊNCIAS BIBLIOGRÁFICAS}

AMANTE, Maria de Fátima. A reprodução quotidiana dos mitos nacionais: o caso de Nuno Álvares Pereira. In: AMANTE, Maria de Fátima. (Coord.). Identidade nacional. Entre o discurso e a prática. Porto: Fronteira do Caos Editora, 2011.

CARDIM, Pedro. Centralização política e estado na recente historiografia portuguesa sobre o Portugal do Antigo Regime. Nação e Defesa, n. 87, 1998.

COSER, Miriam Cabral. A dinastia de Avis e a construção da memória no reino português: uma análise das crônicas oficiais. Cadernos de Ciências Humanas. v. 10, n. 18, jul./dez. 2007, p. 703-727.

BOXER, C. R. O império marítimo português (1415-1825). Lisboa: Edições 70, 1969.

COELHO, Maria Helena da Cruz. Entre poderes. Análise de alguns casos na centúria de quatrocentos. Revista da Faculdade de Letras. Porto: [s.n.], 1990. 2a Série, v. 7.

ELIADE, Mircea. Mito do eterno retorno. São Paulo: Mercuryo, 1992.

ELIADE, Mircea. Mito e realidade. São Paulo: Perspectiva, 1972. 
GODINHO, Vitorino Magalhães. Portugal, a emergência de uma nação. Lisboa: Colibri, 2004.

JUSTINO, David. Estado, território e nação: dualismos múltiplos nas representações da identidade Nacional. In: AMANTE, Maria de Fátima (Coord.). Identidade nacional. Entre o discurso e a prática. Porto: Fronteira do Caos Editora, 2011.

LE GOFF, Jacques. História e memória. Campinas/São Paulo: Unicamp, 2012.

MATTOSO, José. A formação da nacionalidade. In: TENGARRINHA, José (Org). História de Portugal. São Paulo: Edusc/Unesp/Instituto Camões, 2000, p. 7-18.

MATTOSO, José (Org.). História de Portugal. A monarquia feudal. v. 2. Lisboa: Estampa, 1992.

MATTOSO, José. História de Portugal. v. 1. Lisboa: Círculo de leitores, 1992.

MATTOSO, José. Identificação de um País: Ensaio sobre as Origens de Portugal (1096-1325). Lisboa: Estampa, 1985.

MENDONÇA, Manuela. Batalhas da História de Portugal: Guerra Luso-Castelhana. v. 6.

NASCIMENTO, Denise da Silva Menezes do. O poder negociado. Os crimes contra a pessoa e sua honra no reinado de D. João II. [Tese de Doutoramento]. São Paulo: USP, 2009.

PAMPLONA, Marcos A. Nação. In: FERES JUNIOR, João (org.). Léxico da história dos conceitos políticos do Brasil. Belo Horizonte: UFMG, 2009.

PEREIRA, José Esteves. Identidade, Estado e o paradigma da centralização. In: AMANTE, Maria de Fátima (Coord.). Identidade Nacional. Entre o discurso e a prática. Porto: Fronteira do Caos Editora, 2011.

POLLAK, Michael. Memória, esquecimento, silêncio. Revista Estudos Históricos. Rio de. Janeiro, v. 2, n. 3, p. 3-15, 1989.

RESENDE, Garcia de. Crônica de Dom João I/ e miscelânea. Lisboa: Imprensa Nacional/Casa da Moeda, 1973.

RICOEUR, Paul. A memória, a história e o esquecimento. Trad. Alain François et al. Campinas/São Paulo: Editora da UNICAMP, 2007.

RICOEUR, Paul. Memória história e esquecimento. Conferência escrita e proferida em inglês em 8 de março de 2003 em Budapeste sob o título "Memory, history, oblívio". Disponível em http://www.uc.pt/fluc/uidief/textos ricoeur/memoria historia.

SANTOS, Joaquim Manuel Rodrigues dos. "Aqui nasceu Portugal" - da sublimação do castelo de São Mamede em Guimarães à sua conversão em arquétipo cultural do castelo português. In: ROSAS, Lúcia; SOUSA, Ana Cristina; BARREIRA, Hugo (ed.). Genius Loci: lugares e significados. Porto: CITCEM - Centro de Investigação Transdisciplinar "Cultura, Espaço e Memória”, 2017, v. 2, p. 159-169.

SERRÃO, Joel (Dir.), MARQUES, A. H. Oliveira (Coord.). A nova história da expansão portuguesa. v. 2: A expansão quatrocentista. Lisboa: Estampa, 1998.

SERRÃO, Joel. MARQUES, A. H. de Oliveira (org.). Portugal em definição de fronteiras (1096-1325): Do Condado Portucalense à crise do século XIV. Nova História de Portugal. Lisboa: Presença, 1996. Vol. III. 
SILVA, Manuel Telles da. Vida e feitos de D. João II. Lisboa: Imprensa Nacional - Casa da Moeda, 1989. SOBRAL, José Manuel. Da casa à nação: passado, memória, identidade. Etnográfica, v. III (1), 1999, p. 71-86.

SOUSA, Armindo de. Imagens e utopias em Portugal nos fins da Idade Média: a imagem consentida de rei. Revista Portuguesa de História. Coimbra, 1996. Tomo XXXI. v. 2.

THIESSE, Anne-Marie. A Europa das Nações. In: CUNHA, Carlos Manuel Ferreira da (ed.). Escrever a nação: literatura e nacionalidade (uma antologia). Guimarães: Opera Omnia, 2011, p. 69-76. 